\title{
Venezuela: An Unstable Equilibrium
}

\author{
Venezuela: un equilibrio inestable
}

\section{DIMITRIS PANTOULAS}

IESA Business School, Venezuela

\section{JENNIFER MCCOY}

Georgia State University, USA

\begin{abstract}
Venezuela's descent into the abyss deepened in 2018. Half of the country's GDP has been lost in the last five years; poverty and income inequality have deepened, erasing the previous gains from the earlier years of the Bolivarian Revolution. Significant economic reforms failed to contain the hyperinflation, and emigration accelerated to reach three million people between 2014 and 2018, ten percent of the population. Politically, the government of Nicolás Maduro completed its authoritarian turn following the failed Santo Domingo dialogue in February, and called for an early election in May 2018. Maduro's victory amidst a partial opposition boycott and international condemnation set the stage for a major constitutional clash in January 2019, when the world was divided between acknowledging Maduro's second term or an opposition-declared interim president, Juan Guaido.
\end{abstract}

Key words: Venezuela, Nicolás Maduro, economic crisis, hyperinflation, elections, electoral legitimacy, authoritarianism, polarization

\section{RESUMEN}

El descenso de Venezuela en el abismo se profundizó en 2018. La mitad del PIB se perdió en los últimos cinco años; la pobreza y la desigualdad de ingresos se profundizaron, anulando los avances de los primeros años de la Revolución Bolivariana. Las importantes reformas económicas no lograron contener la hiperinflación y la emigración se aceleró para llegar a tres millones de personas entre 2014 y 2018, el diez por ciento de la población. Políticamente, el gobierno de Nicolás Maduro completó su giro autoritario luego del fracasado proceso de diálogo de Santo Domingo en febrero, y Maduro pidió una elección adelantada en mayo de 2018. La victoria de Maduro en medio de un boicot parcial de oposición y el rechazo internacional, preparó el escenario para un importante choque constitucional en enero de 2019, cuando el mundo se dividiría entre reconocer el segundo mandato de Maduro o un presidente interino declarado por la oposición, Juan Guaidó.

Palabras clave: Venezuela, Nicolás Maduro, crisis económica, hiperinflación, elecciones, legitimidad electoral, autoritarismo, polarización 


\section{INTRODUCTION}

The year of 2018 continued the downward spiral that Venezuela has experienced since at least 2013, as documented in previous annual reviews in this journal. If, in 2017, the country was moving deeper into the abyss, as aptly noted by Julia Buxton (2018), then 2018 was surely the year that the country descended further, to the political, social and economic Hades.

Venezuela's "Bolivarian Revolution" initiated by Hugo Chávez's election in December 1998, had come through booms and busts, and was facing its most severe crisis to date. After Chávez's death in 2013, his successor, Nicolás Maduro, initially struggled to consolidate his own position within chavismo, while the newly emboldened opposition took to the streets in protest and organized to win a decisive victory in the 2015 National Assembly elections for the first time since 1998 (Sagarzazu, 2014; Sánchez Urribarí 2016). This renewed the political conflict as the opposition revived its efforts to remove Maduro from office in 2016, while Maduro surrounded himself with officials who faced high exit costs if the governing PSUV should lose power, thus ensuring their personal loyalty (Cannon and Brown 2017).

The complete exhaustion of Hugo Chavez's Bolivarian project after two decades has accompanied the country's free fall. Despite the internal contradictions and complexity in defining the Bolivarian project (Spanakos and Pantoulas 2017), its legitimation through electoral processes and its aims to eliminate poverty and inequality have been central features since its beginning (McCoy and Neuman 2001). Both of these features were completely erased in 2018 and their opposites - autocratization and deepening poverty and inequality_accelerated at an alarming pace.

Although scholars critical of the Bolivarian project had been warning for years that its defective democracy was autocratizing, the regime's usurpation of the authority of the opposition-controlled National Assembly in 2016 and the tainted elections for the Constituent Assembly and state governors in 2017 marked a clear departure from even defective democracy. In 2018, international acknowledgement of the end of any democratic trappings became explicit as the main opposition parties boycotted the May 20 presidential election and a dozen Western governments refused to recognize the legitimacy of a Venezuelan presidential election for the first time in modern history. Likewise, the acute economic crisis that started in 2015 led the country into a humanitarian emergency, with the lower and lower-middle classes suffering massively, leading millions to emigrate.

The demise of the Bolivarian project did not bring a new vision for the country. Instead, President Nicolas Maduro-Hugo Chavez's handpicked successorsimply moved to entrench his power and ensure the loyalty of his inner circle by enabling ever-expanding corruption, criminal activity and forceful repression of any dissent. After the tumult of the protests of 2017 that paralyzed 
the country, several factors created the conditions for the significant political rebound of Maduro's government: the fatigue of the social resistance to Maduro government; the government's excessive use of violence against demonstrators; and the lack of leadership and vision by the formal opposition parties and their disconnect with the public sentiment. Maduro seized the moment and called for early Presidential elections, using internationally-facilitated political dialogue and electoral processes to further divide the opposition between those calling for broad participation in the elections and those who argued in favor of abstention.

\section{ECONOMY AND SOCIETY}

The country's economic hardships have intensified since Nicolás Maduro won the special election to replace the late President Hugo Chavez in 2013, and Venezuela is undergoing one of the most severe economic and financial crises in its history, and indeed in the contemporary world. A study of the Latinobarometro 2018 regional poll makes a striking observation about the status of the Venezuelan economy. The poll states, "In Venezuela, no one (1\% is statistically not significant) says that there is a good economic situation. It is very exceptional in public opinion studies to find aggregates like this, where nobody declares the existence of a phenomenon. Venezuela will undoubtedly be the object of many studies in this sense" (Latinobarómetro 2018).

Venezuela's macroeconomic position was already deteriorating even before the price of oil plummeted in the second half of 2014. Due to this negative development, since 2014 the Venezuelan government had argued that the opposition and private capital were carrying out an economic war against it, and claimed that data and information about the state of the economy could be used as political weapons against it with significant electoral and political costs (EFE 2015). Thus, official data became scarce and sporadic as the government stopped publishing statistics, and international organizations and scholars were forced to use mostly non-official sources.

After the elections of December 2015, the Venezuelan government published some data (after nearly a year without any) that confirmed that the economy was in a severe recession; the economy as a whole had contracted by $5.7 \%$ in 2015 and $3.9 \%$ in 2014 (CEPAL 2016). The economy continued contracting significantly in the ensuing years. Under the pressure of the IMF, which issued a declaration of censure against Venezuela, the Central Bank of Venezuela published partial data in 2018 showing that the economy contracted by 15.7\% again in 2017 (Ayala 2018). There is no official data for 2018, but estimates from the IMF indicate that the economy further contracted by 18\% (IMF 2019), meaning that Venezuela has lost almost half of its Gross Domestic Product (GDP) in five years, a situation seen only in countries that have suffered extreme natural disasters or wars. 
One of the main reasons for the decline of Venezuela's GDP is the collapse of the oil sector. Deepening its historic reliance on oil revenues coming from the international markets to account for nearly 95\% of Venezuelan exports, the government neglected investment in other essential industries, choosing instead to import most of its goods. Furthermore, although a long commodities boom in the first decade of the 21st century saw oil prices reaching the highest in the country's history, the Chavez and Maduro governments failed to accrue foreign exchange reserves or savings in sovereign funds. Instead, successive governments depleted international reserves, from a high of $\$ 42.054$ billion in 2008 (or $\$ 21.760$ billion in the first year of Maduro government in 2013) to $\$ 9.17$ billion in 2018, the lowest in decades. Consequently, during the Maduro years, Venezuelan imports decreased from \$58.7 billion in 2012 to $\$ 9.1$ billion in 2018, creating severe shortages of food and medicines.

Venezuela is the example par excellence of the "rentier state" in which the petrostate orients its action toward the political distribution of rents rather than the promotion of private investment, production and economic growth (Karl 1997). During 2018, President Maduro acknowledged that the economic model of the country is partially responsible for the country's woes, saying that Venezuela is a "rentier state" and pledging that the country will change its economic model and the rentier state "will never come back" (Arroyo 2018). Nevertheless, the government has taken no steps to reduce the dependence on oil.

\section{KILLING THE GOOSE WITH THE GOLDEN EGG}

Declining oil revenue is the product of both declining world oil prices and a collapse of oil production within the country following years of failures to invest in the company and the loss of managerial and worker expertise following the 2003 oil strike. Venezuela's crude production was 1.3 million barrels per day (mbd) in 2018, according to the Organization of the Petroleum Exporting Countries (OPEC). This is a decrease of $30 \%$ compared to the average output of 2017 (1.9 mbd), which had previously seen the lowest output of the last three decades (OPEC 2019). If we take into the account that Venezuela needs around 400,000 barrels per day for domestic oil consumption, and it has to make oil shipments to China and Russia for debt repayment, and to Cuba (around $80 \mathrm{mil}$ bd) in exchange for the services of its skilled workers (mainly doctors) in the country, then oil income for the country is significantly reduced compared with the recent past.

The end of the spectacular oil price boom began in 2014: average price for the Venezuelan oil in 2014 was $\$ 88.42$ USD per barrel, while the 2015 average was $\$ 44 \mathrm{p} / \mathrm{b}$ and just $\$ 29.5 \mathrm{p} / \mathrm{b}$ in 2016 (MPETROMIN 2016). Alhough the negative oil price trend has since reversed-for 2017 the average oil price was $\$ 46.6 \mathrm{p} / \mathrm{b}$ 
and for 2018 \$63 p/b (MINPET 2019)_actual revenues for the past two years have been almost identical due to the collapse of oil production.

\section{HYPERINFLATION AND THE GOVERNMENT'S REACTIONS}

The most critical and pressing economic issue at hand is hyperinflation-the recurrent increase of prices at a rate of not less than $50 \%$ monthly. Hyperinflation started in 2017 but gained intensity in 2018, especially in the last quarter of the year. Although the government has not provided any data since 2017, the Finance Committee of the National Assembly (AN) monitoring prices announced that inflation in Venezuela closed at 1,698,488\% in 2018 (Callama 2019), with prices doubling every 19 days on average, while the IMF estimated year-end inflation at $929,790 \%$ (IMF 2019). This has left many Venezuelans struggling to afford basic items such as food and toiletries.

The government insists that the country's economic woes are due to crippling sanctions imposed by the U.S., the private sector's speculative behavior and foreign financial centers that induce hyperinflation. However, sober analyses argue that the hyperinflation problem is the result of structural and failed policy decisions. On the structural side, the collapse of oil prices and decreased production resulted in fewer imports, which, in a vicious cycle, has further impeded local production due to the lack of raw materials and import supplies. The fall in national production collapsed the collection of taxes in real terms, generating a huge deficit in public accounts calculated by local firms, and economists close to the government, at the astronomical figure of $15 \%$ or more of GDP (Navarro 2018). The Institute of International Finance, a Washingtonbased association of international financial institutions, estimated the fiscal deficit to have reached 37\% of GDP in 2017 and 2018 (Pérez 2019). With this huge mismatch, the government and the Central Bank had to print new bolivars at a frenetic pace, causing a profound imbalance between money supply and demand: more money chasing fewer products, a combination that triggers prices increase (Prodavinci 2018). On August 17, 2018, the President of the Republic, Nicolas Maduro, admitted that due to the fall in revenues the government had to resort to the issuance of money to be able to support the economic and social model, something that the Constitution of 1999 explicit rejects (article 320) (Aporrea-Agencias 2018).

The national currency - the Bolivar Sovereign (BS) — continued its devaluation in the foreign currency exchange black market; however, in 2018, for first time in years, the devaluation rate was significantly below the inflation rate, meaning that even dollars lost purchasing power, making the country more expensive even in US\$ terms. According to the webpage DolarToday that reports US\$ prices in black market currency trading, one US dollar at the beginning of the year was equivalent to 1.12 BS; by the end of the year, this figure was 720 BS 
to a dollar, meaning that the Bolivar lost $99.8 \%$ of its value (or that the dollar appreciated by about $67,000 \%$ ).

\section{POVERTY}

Chávez's pro-poor social policies helped reduce household poverty and extreme poverty between 1999 and 2012 from $40 \%$ (28.9\% poverty, $10.9 \%$ extreme poverty) in 1998 to around 25\% in 2013 according to official data (19.7\% poverty, $4.9 \%$ extreme poverty) (INE 2019). After that, however, the trend reversed, and by 2018 half Venezuelan households lived in poverty, with $94 \%$ having insufficient funds to cover their living standards, according to the ENCOVI survey of three major Caracas universities (ENCOVI 2018).

Prior improvements in income inequality were also reversed. Nicolás Maduro claimed in his 2019 state of the nation report that in 2018 Venezuela reached "the best Gini coefficient [a measure of inequality] in the history of Venezuela with 0.377"(VTV 2019). Nevertheless, according to ENCOVI, the GINI coefficient in 2017 was actually 0.68, making Venezuela one of the most unequal countries of the world (España and Ponce 2018). This meant that the richest $10 \%$ of the population earned more than $60 \%$ of Venezuela's total income, double the rate they were earning in 2014 (Perez 2019). Furthermore, workers in the formal sector have seen their salaries shattered by galloping inflation while also having to face a crippling of the electricity supply that began in 2017, forcing energy rationing, a reduction in public and private economic activity, and consequently further reducing workers' income.

\section{ECONOMIC POLICY REFORMS}

In August 2018, President Maduro announced wide-ranging reforms to overhaul the country's economy; the Recovery and Economic Prosperity Plan aimed to "stabilize inflation, combat speculation, and lead to economic growth" (Carvajal-Arroyo 2018). The plan included a messy monetary reconversion (the sovereign bolivar was introduced, which has five fewer zeros than its predecessor, the strong bolivar), and an upward adjustment of the price of gasoline with direct subsidies to the population that was never implemented. Maduro also announced some changes in the fiscal and tax system with the explicit, ambitious intention of achieving a fiscal deficit of zero; thus, he increased the Value Added Tax from 12 to 16\%. Similarly, he introduced a tax of up to $2 \%$ on "large financial transactions" (Alba Ciudad and Prensa Presidencial 2018).

Another crucial decision contained in this program was the increase in the minimum wage-including for millions of public sector workers-to 1,800 sovereign bolivars, which is equivalent to an increase of 6000 per cent of the minimum wage from the previous months. In order to mitigate the initial effects 
of the adjustment of the minimum wage on businesses, Maduro proposed that the state would pay the payroll of the small and medium companies for 90 days.

The most important of the changes announced by Maduro in 2018 was the dismantling of the 15-year old currency control system that even economists sympathetic to the government had warned were inhibiting recovery from the recession and providing enormous incentives for corruption (Weisbrot 2017). As the economic crisis deepened, the public and the press focused more on the "boliburgueses" - people linked with the Bolivarian government who had benefited economically-and some press investigations reported that about US $\$ 400$ billion of oil exports revenues have been lost in the last ten years in corruption schemes (Ackerman and Sosa 2018).

Specifically, the government announced the unification of the exchange rates (previously two tiers), the use of the Petro - a new commodity-backed digital currency that the Venezuelan government produces and controls - as an exchange anchor, the implementation of auctions to determine the price of the currency and the modification of the law of illicit currency exchange in order to allow the legalisation of trading in other currencies inside the country for the first time since 2003. Nonetheless, the government did not allow the Bolivar exchange rate to float in the global markets. The Central Bank will have a discretionary role in the currency rate, meaning that the margins for political intervention and currency manipulation remain open.

After Maduro announced most of the above-mentioned measures in late August, stores remained closed for days, with workers feeling anxious about their future. Once businesses re-opened, the lives of Venezuelans complicated further. Businesses and private actors started trading many services and products in US dollars, which meant that prices increased even further and the majority of the Venezuelans-with salaries in the undervalued Bolivar-had little access to them. According to a well-known pollster, only $31 \%$ of Venezuelans have access to dollars (remittances, savings or other activities), with the rest of the population increasingly dependent on the bonuses and the products that the Venezuelan government offers to them at subsidized prices (González 2018).

\section{PROTESTS}

After the nation-wide, opposition-directed daily protests in April-July 2017 petered out, the economic collapse translated to renewed widespread unrest in 2018. The scarcity of food, the crumbling public services (electricity, water, transport) and the continuous increase in prices created social unrest, with lootings and local protests occurring almost daily. In contrast to the 2017 protests, however, in 2018 protests were socially and economically motivated, smallscale, and occurred mainly in the poor neighborhoods of the city, including the traditional electoral base of Maduro's government (Deutsche Welle 2018). The difference in the nature and scale of the manifestations is depicted in 
measurements done by the Venezuelan Observatory of Social Unrest (OVCS), a local NGO that tracks protests in the country. OVCS reported 12,715 protests in 2018, 30\% more than $2017(9,789)$ and a record year in terms of the number of protests (OVCS 2019). The protests belied the apparent political calm, reflecting latent political discontent among a society without the mechanisms to express itself, especially after the failure of the highly visible 2017 protests and their high cost in human lives.

\section{POLITICAL CONTEXT AND ELECTIONS}

Most of the major political events that marked 2018 had their origins in 2017. President Maduro had significant political momentum by the end of 2017 after his electoral coalition won 18 of the 23 governorships in the state elections amidst opposition disarray. Rumors circulated that presidential elections, constitutionally mandated for the calendar year of 2018, could happen as early as March 2018, despite the historic practice of holding elections late in the year to coincide with the inauguration of the new presidential term the following January.

The only constraint on the government's desire for an expedited presidential election was the internationally-facilitated dialogue taking between Maduro's government and an opposition delegation in the Dominican Republic, beginning in late 2017. One of the main objectives of the dialogue process was to draw a roadmap for a transitional period before the presidential elections and an agreement on the conditions for the electoral contest, including the date of the election. After Maduro's unexpected electoral win in the October gubernatorial elections, however, it was clear that the government was not willing to make any significant compromises.

The opposition coalition MUD was internally divided about whether to participate at all in the talks, and those who did intended to show that they had exhausted any possible democratic means of political change (Duno 2017; Buxton 2018). The inability to achieve any substantial agreement such as institutional reform, a transitional government, and clean elections further divided a demoralized opposition, with the more extreme critics raising the question of why they kept talking to an intransigent government that uses negotiation processes just to buy itself time in difficult situations. The radical opposition went so far as to call participation in the negotiations an act of "high treason" (EL Nacional Web 2017).

Finally, after three formal meetings in Santo Domingo in December 2017 and January 2018, the talks failed spectacularly in early February, with the opposition declining to sign an agreement proposed by former Spanish president Rodríguez Zapatero that did not include serious electoral guarantees and Maduro's government arguing that the US government should be blamed for the negotiation failure (Ramsey 2018). 
The immediate government response to the failure of the negotiations was to call for early presidential elections for April 22, 2018. The MUD decided to boycott the election, calling it a simple "electoral simulation" with no guarantees (Leon 2018b), even while some opposition voices argued for using all available means, including voting, to keep pressure on the government and not hand it an easy victory.

The MUD's decision to boycott the elections did not bring any significant popular backlash. The majority of the population had little confidence in the National Electoral Council (CNE) and 9 out of 10 opposition voters viewed the CNE as biased in favor of the government and willing to tamper with the electoral results, as it did it twice in 2017 (Martínez 2018b). Thus, a great part of the opposition calculated that participating in the election would only grant legitimacy to a sham election, and that voting would not be a means to trigger a political change in the country. Parts of the international community subscribed to the boycotting, saying that an electoral process without electoral guaranties lacks any legitimacy and credibility and should not be internationally recognized (Lima Group 2018). The president of the Organization of American States (OAS), Luis Almagro, went so far as to argue that possible opposition participation in the election would be the "worst sanction for the Venezuelans" (Delgado 2018).

Meanwhile, a small opposition faction had been negotiating better election terms and a few weeks later the National Electoral Council postponed the elections until the 20th of May (Martinez and Cawthorne 2018). A former chavista turned opposition governor, Henri Falcón of the Advanced Progressive party, ran for president against Maduro and an evangelist Christian minister, Javier Bertucci. The government agreed to a few improvements in the process, such as extending the voter registration deadline, but the process was still controlled by a politicized CNE favoring the government (Colina and McCoy 2018). The CNE barred high-profile opposition candidates and outlawed the majority of opposition political parties-of 67 political parties registered in 2016, only 17 survived in 2018, of which twelve were allied with the government (Martínez 2018a). Together with other procedural violations, the electoral conditions were extremely favorable to Maduro and were condemned by many local and international organizations (OGCD 2018).

In contrast to 2013 when Maduro ran as Chavez's heir and continuously invoked his name, in 2018 Maduro strove to create his own brand. He used a rainbow of colors and dropped the trademark red color that had symbolized Chavez and his Bolivarian Revolution; the presidential couple was the focus with a reduced mention of Chavez. More substantively, Maduro created a new party called We Are Venezuela (Somos Venezuela) with his civilian allies, though the Socialist Party created by Chavez (PSUV) also continued under such heavyweights as Diosdado Cabello. 
The National Electoral Council (CNE) declared the incumbent president, Nicolas Maduro, the winner of the May 20 presidential vote with 5,823,728 votesan impressive $67.8 \%$ of the votes cast-easily doubling the votes of the other two main contenders (Henry Falcón received 21\% and Javier Bertucci 10.8\%). This is the highest percentage that a presidential candidate had achieved since 1947 when president Romulo Gallegos was elected with $74.3 \%$ of the votes, and significantly higher than Chavez's best electoral score in the presidential elections (63\% in 2006).

The electoral result, however, was a Pyrrhic victory for Maduro. He was the winner of the electoral contest with the highest abstention rate in the history of presidential elections in Venezuela; turnout was just 46.1 per cent, compared with almost $80 \%$ in 2013. In the aftermath of the contest, the opposition candidate Henry Falcón refused to accept the results of the elections because of irregularities found during the electoral process, and almost 50 countries refused to recognize it (Ponte 2018).

\section{THE STATE OF THE OPPOSITION}

After various splits over tactics and strategy, the MUD-the electoral coalition that had dominated opposition politics since 2009-lost its political and organization momentum, with some even writing its obituary (Moleiro 2018). With the MUD out of the game, three wings dominated the opposition panorama in 2018, creating a relatively weak opposition to Maduro's government.

The first wing was a new political platform called Frente Amplio (FA) that was created in March 2018. FA is a platform that integrates various established political forces together with social organizations, such as student and labour unions, university professors, chavista dissidents, and even young people of the "Resistance." Despite the efforts of the FA's members to present the new coalition as something inclusive and bottom-up, it was clear that the political parties-all of them members of the MUD who had decided to boycott the presidential elections-had a leading role in this coalition. The coalition did not have a precise mechanism of decision-making nor a clear strategy of action against the government; its main objective was to oppose the presidential elections. After the elections, the platform lost steam.

The second wing consisted of the most radical parts of the Venezuelan opposition who continued to lobby for an international "humanitarian intervention," believing it was impossible to achieve political change with the actions of the country's opposition alone. In the fall of 2017, they created a loose civic-political alliance called Soy Venezuela, headed by Maria Corina Machado and Antonio Ledezma, both long-time voices of the radical opposition. Despite their visibility in social media, however, they did not achieve a significant political movement or citizen mobilization in 2018. 
The third wing of the opposition in 2018, represented by the presidential candidate Henry Falcón, together with many analysts and political consultants, continued to insist on the electoral route, calling for a massive vote in the elections of May 20. Once the elections occurred, Falcón and his allies virtually disappeared from the opposition debate.

Another factor that contributed to the weak presence of the Venezuelan opposition in 2018 was the lack of leadership of the National Assembly (AN), the only state power controlled by the Venezuelan opposition. The largest opposition parties-Accion Democratica (AD), Primero Justicia (PJ), Voluntad Popular (VP), and Un Nuevo Tiempo (UNT) - had agreed after the victorious parliamentary elections of 2015 that they would rotate the National Assembly's presidency annually. In 2018, it was the turn of the moderate UNT to propose the Assembly's president. They chose the septuagenarian Omar Barboza. A moderate politician with little prominence in his political party or national politics, Barboza did not have the power to impose a clear line in the AN's positions and dedicated most of his time to keeping the balance between the different opposition fractions. This was a striking difference with the previous two years, when the National Assembly was led first by Henry Ramos Allup (AD) and then Julio Borges (PJ), both well-known politicians with presidential ambitions and significant power inside their parties.

\section{FEARS OF COUP AND THE DRONE ATTACK}

Following the election, Maduro moved to strengthen his position within his party, essentially agreeing to a form of power-sharing within the PSUV between himself and Cabello, after they dominated the presidential election votes within the coalition (Pérez Hernáiz and Smilde 2018). Nevertheless, Maduro continued to be concerned about a possible military coup d'état (Nederr 2018). Throughout the year, he took actions to try to forestall such an event. Early in the year, Maduro expelled 24 officers from the army (many of them retired) and the government arrested 19 Venezuelan army officers on charges of rebellion and treason (Mayorca 2018; EFE 2018b). The government then arrested Miguel Rodriguez Torres, the powerful former interior minister (under Maduro) and intelligence chief (under Chavez), accusing him of conspiracy and actions against democracy (Méndez-Lárez 2018).

On August 4, 2018, a visible threat shook the government. Maduro was leading a commemoration ceremony for the 81st anniversary of the National Guard when a drone carrying an explosive charge exploded near him. The president was unhurt, but television images showed the assembled soldiers breaking ranks and running in panic after the bomb exploded. Shortly after, the government announced that they had identified those responsible and arrested various individuals. Three days later, Maduro accused two opposition deputies-a young and irreverent politician, Juan Requesens, and Julio Borges, a leading 
opposition figure who was already in exile in Colombia-of being complicit in the attack against him. The government (through the National Constituent Assembly) stripped both men of their legislative immunity and arrested Requesens.

The Venezuelan state continued its investigations into the drone attack and made several more arrests in the following months. In one case, the government arrested a Caracas city councilor, Fernando Albán of Primero Justicia, who was found dead under unclear circumstances shortly afterward. According to the official version of events, Alban committed suicide by jumping from the window of his detention cell in the headquarters of the SEBIN state security agency. The opposition argued that the death of Alban was the product of torture and that police officers threw his body from the window after he had died from torture.

The drone attack demonstrated three things: first, the deterioration of Venezuela's intelligence capacity to detect and dismantle an amateurish attack; second, the potential for such an attack to either lead the country into violent chaos or to lead to a real military dictatorship, as the opposition was in a state of disarray (Smilde 2018); and third, any failed violent attempt to overthrow Maduro is likely to further legitimate crackdowns on Venezuelan opposition politicians inside the country.

\section{INTERNATIONAL RELATIONS}

International polarization over Venezuela was already clear in 2017, with the formation of the Lima Group of a dozen Latin American countries (and Canada) critical of the Maduro regime and the US spearheading a sanctions movement on the one hand, and China and Russia supporting the Maduro government politically and financially on the other hand (Buxton 2018). This polarization crystallized in 2018 with the refusal of over 40 Western countries to recognize Maduro's re-election in May, and Turkey and Iran joining Russia, China, Cuba, Bolivia and Nicaragua in continuing to support Maduro.

In Latin America, a wave of right-wing electoral victories continued into 2018, with conservative governments winning presidential elections in Colombia, Chile, and Brazil. Only Mexico went the opposite direction. The Lima Group thus became more pronounced in its criticism, and Mexico dropped out of it. Regional governments struggled to handle the rapidly growing migration flow from Venezuela, and Peru and Ecuador announced measures to require valid passports to enter, which most Venezuelans could not get (Ramsey 2018b). Colombia, on the other hand, on the frontline with a long porous border with Venezuela, welcomed the migrants and attempted to register them and offer work permits. By the end of 2018 nearly 1.5 million Venezuelans had emigrated to Colombia-a huge number that threatened to engulf border communities (Badour 2019). 
Meanwhile, the Trump administration continued to deepen its sanctions policy, which had expanded from individual sanctions to national financial sanctions in August 2017. In March 2018, President Trump issued E.O. 13827 to prohibit transactions involving the petro, Venezuela's new digital currency developed to circumvent sanctions. And in May 2018, President Trump issued E.O. 13835, prohibiting the purchase of Venezuelan debt. Finally, on November 1, 2018, President Trump issued E.O. 13850, establishing a framework to block the assets of or transactions with persons deemed corrupt or operating in Venezuela's gold sector. This framework would be applied in 2019 (Congressional Research Service 2019).

A debate over the impact of the August 2017 financial sanctions imposed by the U.S. emerged in two papers published in 2019. In a paper by the Center for Economic and Policy Research, Weisbrot and Sachs (2019) argue that the sanctions were responsible for steep drops in oil production, access to credit markets and thus inability to restructure debt, and imports of food and medicines, resulting in higher mortality rates. In a rebuttal, however, a Brookings Institution analysis demonstrated that the sharp deterioration in all of these trends had occurred between 2013 and 2017. Continued deterioration in 2018 may have been exacerbated by the sanctions, but it was not the predominant cause of the drops (Bahar et al. 2019).

China, Russia, and Cuba continued their political and material support for the Maduro government. After suspending new loans since 2015, Maduro reportedly secured a new \$5 billion loan from China in September 2018 (Bloomberg News, 2018). Russia continued to be a lender of last resort and reportedly signed deals for enhanced oil and gold production in a Maduro visit to Moscow at year's end. Russia then flew two nuclear-capable long-range bomber jets to Caracas, provoking an irate response from the United States (Osborn 2018). Meanwhile, Maduro resumed shipments of oil to Cuba, which had not been regular since 2017, in exchange for continued support of Cuban doctors, teachers, intelligence and security agents (Parraga 2018).

Turkey became an important new ally of Venezuela, after having stopped an Iranian shipment of equipment to Venezuela at the request of the United States in 2009. During 2018, commercial trade exploded between the two countries. Turkey supplied Venezuela with the bulk of its food imports for subsidized food bags, and Venezuela exported its gold to Turkey in a bid to circumvent U.S. sanctions (Oner 2019). In a December 2018 visit by President Erdogan to Caracas, the two presidents expressed their intention to cooperate not only in gold trade but also mining, while Erdogan pledged to support Maduro's renewed mandate despite international criticism of the 2018 elections (Leon 2018c). 


\section{CONCLUSIONS}

After a tumultuous 2017 rocked by sustained opposition protests, the election of a parallel political body in the National Constituent Assembly, and internationally-facilitated dialogue raising hopes of an electoral transition, the year of 2018 returned to an apparently stable equilibrium with the government fully in control. The May 20 presidential election demonstrated the government's move away from attempting to maintain electoral legitimacy, a decision already evident in 2017 when the government resorted to outright fraud for the first time (no longer relying on a severely unfair process to win).

But the growing international condemnation from the hemisphere and Europe, and the continued slide into sustained recession, hyperinflation and crisis in social indicators reflected the underlying instability and fragility of the regime. The government's inability to contain the socio-economic crisis with half-baked reforms led accelerated emigration, as three million Venezuelans have left the country since 2015 . The pressure on neighboring states receiving these refugees and immigrants added to the international urgency to do something to contain the crisis and its spillover.

This situation set the stage for a monumental political and constitutional clash in January 2019, when Maduro was sworn in for a second term and nearly 50 countries refused to recognize him. Shortly thereafter, a change in control of the National Assembly produced a new strategy devised by the leaders of the Popular Will (Voluntad Popular) party to name a young, relatively unknown deputy, Juan Guaido, as president of the Assembly in its annual rotation. Guaido, consulting with his mentor Leopoldo Lopez, still under house arrest, then declared on January 23 that he was filling a constitutionally-mandated vacuum of power as second in line for the presidency, given the illegitimacy of Maduro's 2018 election. Thus began a new stage in the Venezuelan crisis, with a newly resurgent opposition and a polarized international community treating Venezuela as a proxy contest between the U.S. and Russia.

\section{REFERENCES}

Ackerman, Boris and Rosa Sosa. 2018, 20th of December. "Enchufados chavistas robaron a Venezuela al menos \$385.000 millones." Retrieved 10 of May 2019 from http:// elestimulo.com/elinteres / analisisenchufados-chavistas-robaron-a-venezuela-al-menos-385-000-millones /

AFP. 2018, 31 July. "Venezuela's President Admits Economy Has Failed." Retrieved 3 May 2019 from https://www.france24.com/en/20180731-venezuelas-president-admits-economy-has-failed

Alba Ciudad and Prensa Presidencial. 2018, 17 August. "Maduro fija el salario mínimo a 1800 bolívares soberanos: Asumirá el diferencial de nóminas en pequeña y mediana industria por 3 meses." Retrieved 1 April 2019 from https://albaciudad.org/2018/08/ maduro-salario-minimo-agosto-2018-bolivares-soberanos-petro/ 
Aporrea-Agencias. 2018, 18 August. "Presidente Maduro reconoció que su gobierno ha emitido dinero no orgánico. 'Así es la vida y nos tocó jugar así'." Retrieved 1 May 2019 from https://www.aporrea.org/economia/n329973.html.

Arroyo, Ingrid. 2018, 27 August. "Venezuela entre el modelo post-rentista, la burguesía parasitaria y la guerra económica." Retrieved 1 May 2019 from http://www.presidencia. gob.ve/Site/Web/Principal/paginas/classMostrarEvento3.php?id_evento=11011

Ayala, Ivonne. 2018, 30 January. “BCV reportó inflación de 860\% en 2017 al FMI." El Universal, Caracas.

AVN. 2018, 3 June. "Presidente Maduro evaluó como positiva primera semana de diálogo nacional". Retrieved 2 January 2019 from http://www.psuv.org.ve/temas/noticias/ presidente-maduro-evaluo-como-positiva-primera-semana-dialogo-nacional

Baddour, Dylan. 2018, 30 January. “Colombia's Radical Plan to Welcome Millions of Venezuelans." The Atlantic. Retrieved 25 January 2019 from https://www.theatlantic.com/ international/archive/2019/01/colombia-welcomes-millions-venezuelans-maduro-guaido/581647/

Bahar, Dany, Sebastian Bustos, José Morales and Miguel Á. Santos. 2019. "Impact of the 2017 Sanctions on Venezuela: Revisiting the Evidence." Brookings Institution Policy Brief. Retrieved 10 May 2019 from https://www.brookings.edu/wp-content/uploads/2019/05/impact-of-the-2017-sanctions-on-venezuela_final.pdf

Bloomberg News. 2018, 13 September. "China to Lend Venezuela \$5 Billion as Maduro Visits Beijing". Retrieved 4 Abril 2019 from https://www.bloomberg.com/news/articles/2018-09-13/china-to-give-venezuela-5-billion-loan-as-maduro-visits-beijing.

Bravo, Isnardo. 2018, 29 June. “¿Es un peine la historia de Óscar Pérez, el piloto que voló un helicóptero sobre el TSJ?" Retrieved 1 January 2019 from https:/ /informe21.com/ politica / es-un-peine-la-historia-de-oscar-perez-el-piloto-que-volo-un-helicoptero-sobre-el-tsj

Buxton, Julia. 2018. "Venezuela: a las puertas del abismo." Revista de Ciencia Política 38 (2): 409-428.

Callama, Barbara. 2019, 9 January. "Asamblea Nacional: Inflación de 2018 cerró en 1.698.488\%". El Universal, Caracas.

Cannon, Barry and John Brown. 2017. "Venezuela 2016: The Year of Living Dangerously." Revista de Ciencia Política 37 (2): 613-633.

Carvajal-Arroyo, Ingrid. 2018, 1 August. "Programa de Recuperación Económica vencerá la inflación y recuperará la capacidad adquisitiva." Retrieved 1 April 2019 from Available from: http://www.presidencia.gob.ve/Site/Web/Principal/paginas/classMostrarEvento3.php?id_evento=11081

CEPAL. 2016. Estudio Económico de América Latina y el Caribe. Santiago: CEPAL.

Colina, Griselda and Jennifer McCoy.2018, 18 May. “Venezuela Elections 2018: Evaluating Electoral Conditions in an Authoritarian Regime." LSE Latin America and Caribbean Blog. Retrieved 5 April 2019 from https://blogs.lse.ac.uk/latamcaribbean/2018/05/18/ venezuela-elections-2018-evaluating-electoral-conditions-in-an-authoritarian-regime/

Congressional Research Service. 2019, 8 May. "Venezuela: Overview of U.S. Sanctions." Retrieved 8 May 2019 from https:// fas.org/sgp/crs/row/IF10715.pdf

Delgado, Antonio María. 2018, 20 January. "Almagro: elección presidencial sólo hundiría a Venezuela en seis años más de dictadura." Retrieved 5 April 2019 from: https:/ / www.elnuevoherald.com/noticias/mundo/america-latina/venezuela-es/article195759464.html

Deutsche Welle. 2018, 13 January. "Nuevos saqueos y protestas por falta de alimentos se registran en Venezuela." Retrieved 1 March 2019 from http://www.dw.com/ es/nuevos-saqueos-y-protestas-por-falta-de-alimentos-se-registran-en-venezuela/a-42139404

Duno, Isaac. 2017, 14 of September. "MUD sobre el diálogo: Nuestro objetivo fundamental es salvar a Venezuela." Retrieved 30 January 2019 from https://www.panorama.com. 
ve/politicayeconomia/MUD-sobre-el-dialogo-Nuestro-objetivo-fundamental-es-salvar-a-Venezuela-20170914-0120.html

EFE. 2015, 7 October. "Venezuela no revela datos de inflación porque está 'en guerra', dice diputado." Retrieved 20 March 2018 from https://www.elnuevoherald.com/noticias/mundo/america-latina/venezuela-es/article38142429.html

EFE. 2018b, 2 March. "Maduro degrada y expulsa de las fuerzas armadas a varios militares opositores." Retrieved 20 February 2019 from https://www.efe.com/efe/america/ politica/maduro-degrada-y-expulsa-de-las-fuerzas-armadas-a-varios-militares-opositores / 20000035-3541015

El Nacional Web. 2017, 10 November. “Aristeguieta Gramcko: ir al diálogo es traición a la patria." Retrieved 1 March 2019 from http://www.el-nacional.com/noticias/politica/ aristeguieta-gramcko-dialogo-traicion-patria_211247

ENCOVI. 2018, 30 November. "Encuesta Nacional de Condiciones de Vida 2018. Avances de Resultados." Retrieved 1 May 2019 from http://elucabista.com/wp-content/uploads/2018/11/RESULTADOS-PRELIMINARES-ENCOVI-2018-30-nov.pdf

España, Luis Pedro and María Gabriela Ponce. 2018, 22 August. "Venezuela es el país más desigual del continente: ¿Qué pasará con la desigualdad social después del 17A?" Prodavinci. Retrieved 20 February 2019 from https://prodavinci.com/venezuela-esel-pais-mas-desigual-del-continente-que-pasara-con-la-desigualdad-social-despuesdel-17a/

González, Adriana. 2018, 12 November. "En Venezuela ya todo se transa en dólares." Retrieved 12 March 2019 from https:/ /www.panorama.com.ve/politicayeconomia/EnVenezuela-ya-todo-se-transa-en-dolares-20181112-0008.html

IMF. 2019. "Data Mapper, World Economic Outlook (April)". Washington. Retrieved 1 May 2019 from https://www.imf.org/external/datamapper/PCPIPCH@WEO/OEMDC/ ADVEC/WEOWORLD/VEN/BRA/COL

INE. 2019. "Hogares pobres por Necesidades Básicas Insatisfechas (NBI), 1998-2015." Retrieved 1 May 2019 from http://www.ine.gov.ve/index.php?option=com_content\&view=category\&id=104\&Itemid $=45$

Karl, Terry Lynn. 1997. The Paradox of Plenty: Oil Booms and Petro-States. London: University of California Press.

Latinobarómetro. 2018. “Informe Latinobarómetro 2018." Santiago de Chile. Retrieved 3 May 2019 from www.latinobarometro.org.

Leon, Ibis. 2018a, 31 July. "Marypili Hernández sobre IV Congreso del PSUV: 'Adiós a la democracia participativa'." Retrieved 3 May 2019 from http:/ / efectococuyo.com/politica/marypili-hernandez-sobre-iv-congreso-del-psuv-adios-a-la-democracia-participativa/

Leon, Ibis. 2018b, 21 February. "MUD confirma que no participará en 'simulacro electoral' y llama a crear 'frente nacional'." Retrieved 4 February 2019 from http:/ / efectococuyo.com/politica/mud-confirma-que-no-participara-en-simulacro-electoral-y-llama-a-crear-frente-nacional/

Leon, Ibis. 2018c, 3 December. "Maduro invita a Erdogan a explotar oro, diamante y coltan." Retrieved 4 February 2019 from http:/ / efectococuyo.com/politica/maduro-invita-aerdogan-a-explotar-oro-diamante-y-coltan-en-el-pais /

Lima Group. 2018, 23 January. "Statement of the Fourth Meeting of the Lima Group on the Situation in Venezuela." Retrieved 24 March 2019 from https://international.gc.ca/ world-monde/international_relations-relations_internationales/latin_america-amerique_latine/2018-01-23-lima_group-groupe_lima.aspx?lang=eng

McCoy, Jennifer and Laura Neuman. 2001. "Defining the 'Bolivarian Revolution': Hugo Chavez's Venezuela." Current History 100 (643): 80-84.

Martinez, Ana Isabel and Andrew Cawthorne. 2018, 1 March. "Venezuela Postpones Presidential Election to May 20." Retrieved 30 March 2019 from https://www.reuters.com/article/us-venezuela-politics/venezuela-postpones-presidential-election-to-late-may-idUSKCN1GD5TM 
Martínez, Eugenio. 2018a, 3 February. "Sobre la ilegalización de partidos en Venezuela". Retrieved 20 March 2019 from https://prodavinci.com/sobre-la-ilegalizacion-de-partidos-en-venezuela/?platform=hootsuite

Martínez, Eugenio. 2018b, 13 April 2018 “Qué dicen las encuestas sobre la situación política en Venezuela?" Retrieved 30 April 2019 from https://prodavinci.com/que-dicen-las-encuestas-sobre-la-situacion-politica-en-venezuela /

Mayorca, Javier Ignacio. 2018, 8 March. "Descontento en el Ejército". Retrieved 4 May 2019 from https://talcualdigital.com/index.php/2018/03/08/28172/

Méndez-Lárez, Ingrid. 2018, 13 March. "VIDEO: Las razones del Gobierno para detener a Rodríguez Torres \#13Mar." Retrieved 3 March 2019 from https://www.elimpulso. com/2018/03/13/video-la-razones-del-gobierno-detener-rodriguez-torres-13mar/

MINPET. 2019. "Evolución de Precios." Retrieved 14 April 2019 from http://www.minpet. gob.ve:81/visew/petroleo.php

Moleiro, Alonso. 2018, 22 October. "La alianza opositora venezolana certifica su fin". Retrieved 1 January 2019 from https://elpais.com/internacional/2018/10/22/america/1540179239_131892.html

MPETROMIN, 2016. "Precios de Petroleo". Retrieved 20 January 2017 from http://www. mpetromin.gob.ve/portalmenpet/secciones.php?option=view\&idS=45

Myers, David J. 2017. “The Struggle to Legitimate Political Regimes in Venezuela: From Pérez Jiménez to Maduro." Latin American Research Review 52 (4): 711-719.

Navarro, Ingrid. 2018, 18 June. "Faría afirma que el déficit fiscal supera 15\% del PIB." Retrieved 8 May 2019 from http://www.eluniversal.com/economia/12560/faria-afirma-que-el-deficit-fiscal-supera-15-del-pib

Nederr, Sofia. 2018 13th of March. "Aseguran que persecución contra militares obedece al temor de Maduro." Retrieved 1 February 2019 from http://www.el-nacional.com/ noticias / politica/aseguran-que-persecucion-contra-militares-obedece-temor-maduro_226593

OGCD. 2018, 3 December. "10 Razones para desconocer las presidenciales del 20 de mayo en Venezuela." Retrieved 20 February 2019 from http://www.observademocracia.org/index.php/2019/03/12/10-razones-para-desconocer-las-presidenciales-del-20-de-mayo-en-venezuela/

Oner, Imdat. 2019, 24 January. "Why Turkey's Erdogan backs Embattled Maduro Against Protestors." Retrieved 19 May 2019 from https://ahvalnews-com.cdn.ampproject. org/c/s/ahvalnews.com/node/37289?amp

OPEC, 2019, 20 January. "Monthly Oil Market Report January 2019." Retrieved 20 July 2019 from https://www.opec.org/opec_web/static_files_project/media/downloads/ publications/MOMR\%20January\%202019.pdf

Osborn, Andrew. 2019, 11 December. "Russian Nuclear-Capable Bomber Aircraft Fly to Venezuela." Retrieved 18 February 2019 from https://www.reuters.com/article/us-venezuela-russia-airforce/russian-nuclear-capable-bomber-aircraft-fly-to-venezuela-angering-u-s-idUSKBN1OA23L

OVCS. 2019, 18 January. “Conflictividad social en Venezuela 2018." Retrieved 18 March 2019 from http://www.observatoriodeconflictos.org.ve/tendencias-de-la-conflictividad/ conflictividad-social-en-venezuela-2018

Parraga, Mariana. 2018, 13 September. "Venezuela resumes domestic crude exports to Cuba: documents." Retrieved 3 March 2019 from https://www.reuters.com/article/ us-venezuela-cuba-oil/venezuela-resumes-domestic-crude-exports-to-cuba-documents-idUSKCN1LT309

Pérez, Santiago. 2019, 25 March. "Venezuela's Economic Collapse Explained in Nine Charts." Retrieved 19 May 2019 from https://www.wsj.com/articles/venezuelas-economic-collapse-explained-in-nine-charts-11553511601

Pérez Hernáiz, Hugo and David Smilde. 2018, 27 July. "Amidst Calls for Self-Criticism, Venezuela's Socialist Party Approaches its Fourth Congress." Retrieved 2 May 2019 from 
https:/ /venezuelablog.org/amidst-calls-self-criticism-venezuelas-socialist-party-approaches-fourth-congress/

Ponte, Gabriela. 2018, 24 May. "Estos son los 15 países que reconocen la victoria de Maduro." Retrieved 20 March 2019 from https:/ / www.abc.es/internacional/abci-estos-15-paises-reconocen-victoria-maduro-201805241339_noticia.html

Prodavinci, 2018, 2 December. "Hiperinflación: un mapa de propuestas." Retrieved 9 February 2019 from https:/ / prodavinci.com/hiperinflacion-un-mapa-de-propuestas /

Ramsey, Geoff. 2018a, 8 February. “No Deal: Venezuela Talks in 'Indefinite Recess'." Retrieved 23 April 2019 from https://venezuelablog.org/no-deal-venezuela-talks-indefinite-recess/

Ramsey, Geoff. 2018b, 21 August. "Economic Plan Fuels anxiety." Retrieved 19 May 2019 from https:/ / venezuelablog.org/venezuela-weekly-economic-plan-fuels-domestic-anxiety-national-strike-sees-mixed-response/

Ross, Michael. 2001. "Does Oil Hinder Democracy?" World Politics 53 (3): 325-361.

Sagarzazu, Iñaki 2014. "Venezuela 2013: un país a dos mitades." Revista de Ciencia Política 34 (1): 315-328.

Sánchez Urribarrí, Raúl A. 2016. "Venezuela (2015): Un régimen híbrido en crisis." Revista de Ciencia Política 36 (1): 365-381.

Smilde, David. 2018, 10 August. "What a Drone Attack Says About Venezuela's Future." Retrieved 1 February 2019 from https://www.nytimes.com/2018/08/10/opinion/ drone-attack-maduro-venezuela.html

Spanakos, Antony P. and Dimitris Pantoulas. 2017. "The Contribution of Hugo Chávez to an Understanding of Post-Neoliberalism." Latin American Perspectives 44 (1): 7-53.

Sputniknews. 2018, 12 May. "Hay que votar el 20 de mayo en Venezuela como gesto de rebeldía." Retrieved 23 March 2019 from https://mundo.sputniknews.com/america-latina/201805121078631642-elecciones-caracas-mud-rebeldia/

Venezuelanalysis. 2018, 31 May. "International Electoral Accompaniment Missions Declare May 20 Elections Free and Fair." Retrieved 1 May 2019 from https: / / venezuelanalysis. com/analysis/13849

Vinogradoff, Ludmila. 2018, 17 January. "Oscar Pérez, nace un héroe." Retrieved 27 February 2019 from https://abcblogs.abc.es/bochinche-venezolano/politica/oscar-pereznace-un-heroe.html

VTV. 2019, 14 January. "Venezuela alcanzó coeficiente Gini de 0,377 en 2018." Retrieved 1 February 2019 from http:/ /vtv.gob.ve/venezuela-alcanzo-coeficiente-gini/

Weisbrot, Mark. 2017, 26 October. "Can The Venezuelan Economy Be Fixed?" Retrieved 1 February 2019 from https://www.huffpost.com/entry/can-the-venezuelan-econom_b_12647100?utm_hp_ref=world\&ir=WorldPost.

Weisbrot, Mark and Jeffrey Sachs. 2019, April. "Economic Sanctions and Collective Punishment: the Case of Venezuela." CEPR. Retrieved 1 May 2019 from http://cepr.net/ images/stories/reports/venezuela-sanctions-2019-04.pdf

Received: May 20, 2019

Accepted: June 15, 2019

Dimitris Pantoulas is a political consultant and expert on Venezuelan politics. Currently, he is a research fellow at the IESA Business, Caracas-Venezuela. Dimitris' academic research relates to participatory politics, innovative governance, and Venezuelan politics under Chavismo. He is a regular contributor and commentator about Venezuelan politics in many local and international media. E-mail: d.pantoulas@gmail.com and Twitter:@dpantoulas

Jennifer McCoy is professor of political science at Georgia State University and an expert on Venezuelan politics. Her current research is on pernicious political polarization and its harm to global democracy. She is a frequent commentator on Venezuelan politics, a former mediator in Venezuela and author or editor of four books on the country, including International Mediation in Venezuela with Francisco Diez. Email: jmccoy@gsu.edu and Twitter: @jlynnmccoy 